\title{
Proximate and Microbial Profile of Couscous Yoghurt Produced from Soya Milk
}

\author{
Kargbo Samuella, Kargbo Kabba
}

Sierra Leone Agricultural Research Institute, Teko Livestock Research Centre, Makeni, Sierra Leone.

\begin{abstract}
This study investigated the effect of milk type and mixture ratio on the proximate composition and microbial profile counts of couscous yoghurt. Yoghurts were first made from cow milk (CM), soya milk (SM) and equal mixture of both types of milk at ratio 50:50. Couscous was then mixed with yoghurts from cow milk (CMCY); soya milk (SMCY) and cow-soya milk (CSCY) at ratios of 90:10, 80:20 and 70:30 (yoghurt: couscous), $w / w$ for the three respectively. The experiment was designed based on 2 factors (milk type and mixing ratio) at 3 levels, each resulting in a total of 9 treatments. Cow milk yoghurt without couscous was used as the control. Proximate compositions were determined using standard methods. Total viable microbial counts of samples were also determined. There were significant differences $(p<0.05)$ in the proximate composition and CSCY at ratio 70:30 had the highest crude protein. In addition, CMCY at ratio 90:10 recorded the highest mean value for fat, while SMCY at ratio 80:20 and 70:30 recorded the least mean value for fat. All the couscous yoghurt samples had total viable cell counts of $(<9 \log C F U)$ that are within the acceptable range according to Codex Standards. In conclusion, the study has shown that CSCY at 70:30 had the highest nutrient content. Moreover, the products were also found to have low levels of microbial profile.
\end{abstract}

Keywords-Couscous, Microbial Profile, Proximate, Yoghurts.

\section{INTRODUCTION}

Yoghurt is one of the oldest fermented milk products that is consumed all over the world; and it is produced by fermenting milk with lactic acid bacteria which are responsible for the development of the typical yoghurt flavour[7]. Soya bean is economically the most important bean in the world providing vegetableprotein for millions of people and ingredients for hundreds of chemical products [2]. The key benefits are related to the excellent protein content (it contains all 8 essential amino acids) with high levels of essential fatty acids, numerous vitamins, minerals, isoflavones, and fibre[1]. The most nutritious and most easily digested food of the bean family, it is one of the richest sources of proteins in staple foods in the world today. Soya bean is one of the important crops taken into consideration as candidates for genetically modified (GM) foods due to its great demand worldwide [11].Studies carried out by [14] reviled that quality and shelf life of fermented dairy products greatly depends upon the quality of raw milk, low total bacterial counts, absence of antibiotics and bacteriophages. The product is said to be perishable in view of its unused lactose content [5].[13]reported that there is an apparent need for a valuable preservation method to control acidtolerant spoilage yeasts and molds in yoghurt. Micotoxigenic fungi and pathogenic bacteria are able to grow at refrigeration temperature to numbers, which can result in an infection. Changes in the chemical, physical and microbiological composition of yoghurt determine the storage and shelf life of the product.

This study therefore was to determine the suitability of replacing cow milk with soya milk in couscous yoghurt production.

\section{MATERIALS AND METHODS}

\subsection{Location of the Study}

The study was conducted at the Crop Utilization Laboratory of the International Institute of Tropical Agriculture (IITA), Ibadan, South-west Nigeria.

\subsection{Materials}

Soya bean seeds (variety TGX 1987, 62 F) were obtained from IITA headquarters Ibadan. Grains of millet (variety JARANI Brown) were obtained from IITA Kano, northern Nigeria. Fresh cow milk was obtained directly from the livestock farm of the Federal University of Agriculture Abeokuta, Ogun state, Nigeria. Commercially available yoghurt starter cultures (Streptococcus thermophillus and Lactobacillus bulgaricus) sugar and flavouringswere purchased from a reputable source in Abeokuta, Ogun State.

\subsubsection{Soya Milk Preparation}

Soya beans were cleaned manually to remove dust, damaged seeds, weeds, and metals. Pre-cleaned soya beans $(1 \mathrm{~kg})$ were soaked in a 16 Litres clean tap water for 10-12 h. The soaked beans were de-hulled manually and milled into a smooth paste. The paste was mixed with 12 Litres of clean tap water to the thickness of milk and sieved through a muslin cloth into a clean fitted container, using method the described by [10]. 


\subsubsection{Preparation of Yoghurt}

Soya milk and cow milk were pasteurized separately at 82 ${ }^{\circ} \mathrm{C}$ for $30 \mathrm{~min}$ and allowed to cool to $42{ }^{\circ} \mathrm{C}$. Freeze-dried starter culture (Streptococcus thermophillus and Lactobacillus bulgaricus) was dissolved in a small quantity $75 \mathrm{cl}$ of lukewarm milk in a cup and poured into the two milk samples then stirred well. The milk was Incubated at $45{ }^{\circ} \mathrm{C}$ according to manufacturer's instructions for the starter culture until it had reached the desired firmness. Sugar and flavourings were added to the coagulum and, stirred very well. Using method the described by [10].

\subsubsection{Preparation of Couscous}

Grains of millet (variety JARANI Brown) were cleaned, sorted and washed using tap water and were allowed to dry at $55^{\circ} \mathrm{C}$ for $24 \mathrm{~h}$ using box oven drier. Millet grains were then milled using fabricated milling machine into a smooth powder and sieved using $0.04 \mathrm{~mm}$ sieve. Water was sprinkled on the milled millet powder and rolled by hand to form pellet, the pelletized millet was then dried for $5 \mathrm{~h}$ at $55^{\circ} \mathrm{C}$ using box oven to form couscous. The couscous was then steamed for $5 \mathrm{~min}$ in a tight fitted container with boiled water [8].

\subsection{Analyses of yoghurt couscous samples}

\subsubsection{Moisture content determination}

Three grams of the sample was placed in a preheated and weighed metallic dish and dried in a Conventional Oven (Fisher Scientific Isotem oven model 655f) at $105^{\circ} \mathrm{C}$ for $16 \mathrm{~h}$ and then transferred to a dessicator at room temperature to cool. The loss in weight was then calculated, using method described by [3].

\section{CALCULATION}

$$
\begin{aligned}
& \% \text { Moisture Content }=\frac{M_{1}-M_{2}}{M_{1}-M_{0}} \times 100 \\
& \text { Where } \quad \mathrm{M}_{0}=\text { Weight ing of dish and lid } \\
& \mathrm{M}_{1} \text { = Weight in } \mathrm{g} \text { of dish, lid and sample before } \\
& \text { drying } \\
& \mathrm{M}_{2}=\text { Weight in } \mathrm{g} \text { of dish, lid and sample after } \\
& \text { drying }
\end{aligned}
$$

\subsubsection{Ash content determination}

Three grams of the sample was weighed in a dried and pre -weighed crucible and ignited in a muffle furnace (Vulcan 3-1750) at $600{ }^{0} \mathrm{C}$ for $6 \mathrm{~h}$ to complete burning of all organic matter. The crucible was transferred directly to a dessicator, cooled and weighed immediately. Ash content was determined, using the method described by [3].

$\%$

$$
\begin{aligned}
& =\frac{(\text { weight of crucible }+ \text { ash })-(\text { weight of empty crucible })}{\text { Sample weight }} \\
& \times 100
\end{aligned}
$$

\subsubsection{Fat content}

Fat from all the couscous yoghurt samples were extracted by adopting the [4]method using Soxtec extractor. Three grams of the sample was placed in the thimble and fitted into the extractor. The fat was extracted with $80 \mathrm{ml}$ of hexane. The extracted fat in cups was weighed and calculated as percentage fat as indicated below

$$
\% \text { Fat on oil }=\frac{\left(W_{3}-W_{2}\right)}{W_{1}} \times 100
$$

\subsubsection{Crude fibre content determination}

Crude fibre was determined according to [3] method No. 926.09. One gram of the sample was digested with $100 \mathrm{ml}$ of 1.25 percent sulphuric acid with 2- 4 drops of $n$ Octanol added to prevent foaming and then filtered through a sintered glass crucible under vacuum. The residue was then washed with hot deionized water till neutralized; $150 \mathrm{ml}$ of 1.25 percent sodium hydroxide was also used to further digest the samples. Digested material was again filtered and washed with hot water until neutralized. The washed material was dried at 100 ${ }^{\circ} \mathrm{C}$ overnight, cooled in a desiccator and weighed. The dried residues were ignited for $3 \mathrm{~h}$ and the crucible was reweighed with burnt material. Crude fibre was calculated by using the following formula:

$$
\begin{aligned}
& \% \text { crude fibre }=\frac{W_{2}-\left(W_{3}+C\right)}{W_{1}} \times 100 \\
& \mathrm{~W}_{1}=\text { Sample weight }(\mathrm{g}) \\
& \mathrm{W}_{2}=\text { Crucible }+ \text { residue weight after drying }(\mathrm{g}) \\
& \mathrm{W}_{3}=\text { Crucible }+ \text { residue weight after ashing }(\mathrm{g}) \\
& \mathrm{C}=\text { Blank }
\end{aligned}
$$

\subsubsection{Protein content determination}

About $0.200 \mathrm{~g}$ of the dry sample was weighed into a digestion tube, $2.5 \mathrm{ml}$ of $\mathrm{H}_{2} \mathrm{SO}$ and allowed to cool for 10 min, $1 \mathrm{ml}$ of $30 \% \mathrm{H}_{2} \mathrm{O}_{2}$ was added to the sample and heated to $330^{\circ} \mathrm{C}$ for $2 \mathrm{~h}$ and allowed to cool. About $0.200-0.800 \mathrm{ml}$ of $\mathrm{n}$ : $\mathrm{p}$ solution was added to the five standards. The sample and standards were then diluted to the $50 \mathrm{ml}$ mark into cups and $\mathrm{N}$ read on the auto- analyzer machine, using the method described by [6].

\subsubsection{Microbial Determinations}

The total viable count of yeast, mould and bacteria counts of the couscous yoghurt samples were determined using pour plate technique and the appropriate dilution was placed on nutrient agar plates. The plates were incubated for 3-5 days and colony forming units per $\mathrm{ml}$ sample (cfu/ml)using the method of [8].

\subsection{Experimental Design and Statistical Analysis} The experiment was designed based on 2 factors (milk types and mixing ratios) at 3 levels each, i.e., a $3^{2}$ factorial resulting in a total of 9 treatments. Cow milk yoghurt without couscous was used as the control 
The data obtained were subjected to One-way analysis of variance (ANOVA) using Statistical Package for Social Scientists (SPSS) version 21.0 while Duncan's multiple new range $\mathrm{F}$ test was used to compare the means and the least significant difference (LSD). Also the data were subjected to two-way ANOVA to investigate the interaction among the factors.

\section{RESULTS}

Table 1 shows the result for proximate composition of the different mixture ratios of the four different couscous yoghurt types. The values obtained for all the nutrients at different mixing levels of the products revealed significant $(p<0.05)$ differences. It was observed that only the moisture content of cow milk yoghurt (CMY) recorded the higher while cow-soya yoghurt: couscous $(\mathrm{CSCY})$ at ratio $70: 30$ recorded the least value for moisture. CSCY at ratio 70:30 result showed the higher mean value for crude fibre. Also, soya milk yoghurt: couscous (SMCY) at ratio 70:30 and CSCY at ratio 80:20 recorded similar values for crude fibre. Crude fibre for CMY only recorded the least value. It was also observed in this study that ash at ratio 70:30 of CMCY yoghurt and CSCY recorded the highest, while SMCY at ratio 90:10 recorded the least mean value for ash. In addition, CMCY at ratio 90:10 recorded the highest mean value for fat, while SMCY at ratio 80:20 and 70:30 was seen to be lesser for fat. CSCY for carbohydrate at ratio 70:30 recorded the highest value, while the least value was recorded for CMY only. The result obtained for CSCY at ratio 70:30, recorded the highest mean value for crude protein. CMCY at ratio 90:10 and SMCY at ratio 80:20 recorded similar values for crude protein. The crude protein in cow milk yoghurt only was seen to be lower.Table 2 shows the results for microbial profile of the different mixture ratios of the four different yoghurt types. There were significant $(p<0.05)$ differences in the mixture ratio of the products. CSCY at ratio 90:10, CMY that is $100 \%$ control and $\mathrm{CMCY}$ at ratio70:30 recorded the higher mean values for yeast. SMCY at ratio 80:20 recorded the least mean value for yeast. CMCY at ratio 70:30 had the highest mean value for mould, while CSCY at ratio 70:30 recorded the least mean value for mould. CSCY at higher inclusion of the couscous (70:30) elicited more bacteria counts. CMY at 100\% (control), 80:20 and SMCY at 90:10 recorded similar values for bacteria counts. The least value was obtained for SMCY at ratio 80:20.

Table 1: Proximate Composition of different yoghurt mixes with millet couscous

\begin{tabular}{|c|c|c|c|c|c|c|}
\hline Products & Moisture & $\begin{array}{l}\text { Crude } \\
\text { protein }\end{array}$ & $\begin{array}{l}\text { Crude } \\
\text { fibre }\end{array}$ & Ash & Fat & $\begin{array}{l}\text { carbohydrat } \\
\mathrm{e}\end{array}$ \\
\hline $\begin{array}{l}\mathrm{CM} \\
\text { yoghurt } \\
\text { only } \\
\mathrm{CM} \\
\text { Yoghurt: } \\
\text { couscous } \\
\text { mix }\end{array}$ & $86.18 \pm 0.14^{a}$ & $4.23 \pm 0.08^{\mathrm{h}}$ & $0.25 \pm 0.00^{\mathrm{h}}$ & $0.65 \pm 0.01^{\mathrm{d}}$ & $3.45 \pm 0.04^{b}$ & $5.23 \pm 0.13^{\mathrm{j}}$ \\
\hline $70: 30$ & $60.45 \pm 0^{\mathrm{i}}$ & $5.56 \pm 0.17^{\mathrm{b}}$ & $1.85 \pm 0.02^{\mathrm{b}}$ & $0.70 \pm 0.00^{\mathrm{a}}$ & $3.10 \pm 0.00^{\mathrm{d}}$ & $28.34 \pm 0.16^{b}$ \\
\hline $80: 20$ & $63.67 \pm 0^{\mathrm{h}}$ & $\begin{array}{l}5.22 \pm 0.00^{c} \\
d\end{array}$ & $1.51 \pm 0.03^{\mathrm{d}}$ & $0.67 \pm 0.01^{\mathrm{c}}$ & $3.22 \pm 0.00^{\mathrm{c}}$ & $25.71 \pm 0.06^{\mathrm{c}}$ \\
\hline $\begin{array}{l}90: 10 \\
\text { SM } \\
\text { Yoghurt: } \\
\text { couscous } \\
\text { mix }\end{array}$ & $67.52 \pm 0^{\mathrm{f}}$ & $4.80 \pm 0.03^{\mathrm{f}}$ & $1.24 \pm 0.02^{\mathrm{f}}$ & $0.68 \pm 0.01^{\mathrm{b}}$ & $3.56 \pm 0.00^{\mathrm{a}}$ & $22.19 \pm 0.01^{\mathrm{f}}$ \\
\hline $70: 30$ & $69.36 \pm 0^{\mathrm{e}}$ & $\begin{array}{l}4.95 \pm 0.07^{e} \\
f\end{array}$ & $1.56 \pm 0.01^{\mathrm{c}}$ & $0.41 \pm 0.00^{\mathrm{g}}$ & $1.24 \pm 0.00^{\mathrm{i}}$ & $22.48 \pm 0.07^{\mathrm{e}}$ \\
\hline $\begin{array}{l}80: 20 \\
90: 10 \\
\text { CM+SM } \\
\text { Yoghurt: } \\
\text { couscous } \\
\text { mix }\end{array}$ & $\begin{array}{l}70.86 \pm 0^{\mathrm{c}} \\
72.86 \pm 0^{\mathrm{b}}\end{array}$ & $\begin{array}{l}4.79 \pm 0.01^{\mathrm{f}} \\
4.59 \pm 0.00^{\mathrm{g}}\end{array}$ & $\begin{array}{l}1.42 \pm 0.02^{\mathrm{e}} \\
1.06 \pm 0.01^{\mathrm{g}}\end{array}$ & $\begin{array}{l}0.39 \pm 0.01^{\mathrm{h}} \\
0.33 \pm 0.01^{\mathrm{i}}\end{array}$ & $\begin{array}{l}1.26 \pm 0.00^{\mathrm{i}} \\
1.30 \pm 0.00^{\mathrm{h}}\end{array}$ & $\begin{array}{l}21.28 \pm 0.02^{\mathrm{h}} \\
19.86 \pm 0.01^{\mathrm{i}}\end{array}$ \\
\hline 70:30 & $56.79 \pm 0^{\mathrm{j}}$ & $6.28 \pm 0.26^{\mathrm{a}}$ & $2.56 \pm 0.03^{\mathrm{a}}$ & $0.69 \pm 0.01^{\mathrm{a}}$ & $1.76 \pm 0.04^{\mathrm{g}}$ & $31.91 \pm 0.27^{\mathrm{a}}$ \\
\hline
\end{tabular}




$\begin{array}{lllllll}80: 20 & 65.48 \pm 0^{\mathrm{g}} & 5.29 \pm 0.13^{\mathrm{c}} & 1.57 \pm 0.04^{\mathrm{c}} & 0.56 \pm 0.00^{\mathrm{e}} & 1.86 \pm 0.00^{\mathrm{f}} & 25.24 \pm 0.10^{\mathrm{d}} \\ 90: 10 & 69.86 \pm 0^{\mathrm{d}} & 5.05 \pm 0.03^{\mathrm{d}} & 1.09 \pm 0.00^{\mathrm{g}} & 0.50 \pm 0.00^{\mathrm{f}} & 2.00 \pm 0.00^{\mathrm{e}} & 21.50 \pm 0.03^{\mathrm{g}} \\ & \mathrm{e} & & \end{array}$

${ }^{a-j}$ Means within the column with different superscripts differ significantly $(\mathrm{p}<0.05)$.

CM: Cow milk only as control, SM: Soya milk, CM: Cow milk, Cow milk + Soya milk.

Table 2: Microbial profile of different yoghurt mixes with millet couscous

\begin{tabular}{llll}
\hline Products & Mould & Yeast & bacteria \\
\hline CM Yoghurt only & $8.60 \pm 0.02^{\mathrm{bcd}}$ & $8.63 \pm 0.02^{\mathrm{a}}$ & $8.41 \pm 0.03^{\mathrm{bc}}$ \\
& & & \\
CM Yoghurt:Couscous mix & & & $8.30 \pm 0.09^{\mathrm{cd}}$ \\
$70: 30$ & $8.71 \pm 0.05^{\mathrm{a}}$ & $8.62 \pm 0.04^{\mathrm{ab}}$ & $8.40 \pm 0.05^{\mathrm{bc}}$ \\
$80: 20$ & $8.68 \pm 0.04^{\mathrm{ab}}$ & $8.53 \pm 0.03^{\mathrm{bc}}$ & $8.46 \pm 0.05^{\mathrm{b}}$ \\
$90: 10$ & $8.61 \pm 0.03^{\mathrm{bc}}$ & & $8.47 \pm 0.10^{\mathrm{b}}$ \\
& & & $8.21 \pm 0.12^{\mathrm{d}}$ \\
SM Yoghurt:Couscous mix & & $8.44 \pm 0.02^{\mathrm{cd}}$ & $8.43 \pm 0.07^{\mathrm{bc}}$ \\
$70: 30$ & $8.53 \pm 0.04^{\mathrm{cd}}$ & $8.35 \pm 0.10^{\mathrm{d}}$ & \\
$80: 20$ & $8.62 \pm 0.05^{\mathrm{bc}}$ & $8.51 \pm 0.07^{\mathrm{c}}$ & \\
$90: 10$ & $8.59 \pm 0.07^{\mathrm{bcd}}$ & & $8.61 \pm 0.05^{\mathrm{a}}$ \\
CM+SM Yoghurt: Couscous mix & & & $8.35 \pm 0.06^{\mathrm{bcd}}$ \\
$70: 30$ & $8.42 \pm 0.05^{\mathrm{e}}$ & $8.49 \pm 0.07^{\mathrm{c}}$ & $8.31 \pm 0.07^{\mathrm{cd}}$ \\
$80: 20$ & $8.50 \pm 0.10^{\mathrm{de}}$ & $8.49 \pm 0.04^{\mathrm{c}}$ & $8.66 \pm 0.03^{\mathrm{a}}$ \\
$90: 10$ & $8.61 \pm 0.04^{\mathrm{bc}}$ & & \\
\hline
\end{tabular}

a-e means within the same column with different superscript differ significantly $(\mathrm{p}<0.05)$

CM: Cow milk only as control, SM: Soya milk, CM: Cow milk, Cow milk + Soya milk.

\section{DISCUSSION}

The lower moisture values of CMCY, SMCY and CSCY with different ratios when compared with CMY only could be due to the fact that the addition of couscous has increased the solid matter in the different blends of the yoghurt: couscous. This is in agreement with the work of [8] who reported that corn starch in the form of slurry thickened the soya yoghurt. The increased protein content with increasing levels of the couscous inclusion is in contrast to the work of [8] who reported a decreasing level of protein in the evaluation of soya-corn yoghurt. This could obviously be due to the significant quantity of protein in soya milk with couscous [9].The high protein content of the products in this study showed that consumption will contribute to the reduction of protein deficiencies in diets which have become a major challenge in poor nations and in children. It could be observed in this study that crude fibre, ash and carbohydrate assumed similar trends, as reported for protein. This corroborates with the findings of [8]. The increase in ash contents observed in all the products is due to the mineral contents caused by the addition of couscous as reported by [10]. The ash is an index of mineral content which is needed for bone development, teeth formation and body function [15] The low fat contents recorded for the ratios of SMCY and CSCY are an indication of the increased total energy available in the products and the longer shelf life which decreased the chances of rancidity.

The microbial profile count is an index of the level of sanitation and or water quality employed in the handling and processing of the products. All the couscous yoghurt samples had total viable cell counts of $(<9 \log \mathrm{Cfu} / \mathrm{g})$ that are within the acceptable range according to Codex alimentarius standards which stated that a maximum count of $10.0 \mathrm{Cfu} / \mathrm{g}$ microbes is allowedin yoghurt. The products were also entirely found to have low levels of microbial count. Observations in this study indicated that the handling and processing of the various yoghurts mixes with couscous was done under proper hygienic conditions. The levels of mould and yeast obtained in this study were also within the recommended level of $10.0 \mathrm{log}$ $\mathrm{cfu} / \mathrm{g}$ for yeast and mould reported by [12] who stated that levels above $10.0 \mathrm{log} \mathrm{cfu} / \mathrm{g}$ are capable of producing toxic metabolites (mycotoxin e.g., aflatoxin) leading to food poisoning and can cause cancer of the liver in humans. 


\section{CONCLUSIONS}

At the end of this study, the following conclusions were made;

1. According to the results of proximate composition it can be concluded that products prepared from CMCY and CSCY yoghurts at ratios 70:30 had highest nutrient contents than those of SMCY and CMY. The results obtained in this study indicated that the nutrient composition of both yogurt types changed similarly.

2. The products were also found to have low levels of microbial profile which is good for human consumption.

\section{RECOMMENDATION}

It can be recommended that Cow-soya couscous yoghurt should be added in the ratio 70:30 because of its high nutrient contents which will help in overcoming the issue of malnutrition in children.

\section{ACKNOWLEDGMENTS}

I am grateful to the Almighty God for his divine opportunity and inspiration given to me throughout the conduct of this research. My sincere gratitude also goes to my Supervisors, their guidance, encouragement and constructive criticism which have immensely contributed to the success of this research work.

I am indebted to the Government of Sierra Leone (GOSL), the Sierra Leone Agricultural Research Institute (SLARI) and the West African Agricultural Productivity Programme (WAAPP) Sierra Leone for the financial support they offered me during the course of this study; and to staff of IITA headquarters in Ibadan, Nigeria for their laboratory assistance.

\section{REFERENCES}

[1] Alka, D. and Arvind, M. K..'Soybean: a Multifaceted Legume with Enormous Economic Capabilities, Soybean - Biochemistry, Chemistry and Physiology', Prof. Tzi-Bun Ng (Ed.), ISBN, 2011, pp.953-307..

[2] Anonymous Encyclopaedia Britannica, 2014. http://www.britannica.com/plant/soybean

[3] AOAC, 2005. Association of official analytical Chemists-Official Methods of Analysis of the $15^{\text {th }}$ Edition.

[4] AOAC, 2010.Official Methods of Analysis.Association of Official Analitical C hemist.EAU.

[5] Durga, L. C. Sharda, D. and Sastry, M. P. ' Effect of storage conditions on keeping riboflavin and niacin of plain and fruit yoghurt", . Indian Journal of Dairy Science, 1986, pp.404-409.
[6] Kjeldahl. 'Preliminary Total Nitrogen, Method', unpublished.

[7] Masamba, K.G. and Ali, L. 'Sensory Quality Evaluation and Acceptability determination of Yoghurt made from Cow, Goat and Soy milk", African Journal of Food Science and Technology, 2013, pp. 44-47.

[8] Olakunle, M. M. 'Production and Quality Evaluation of Soy-Corn Yoghurt', Advance Journal of Food Science and Technology, 2012, pp. 130-134.

[9] Olaoye, O. A.Onilude, A. A. and Idowu, O. A. 'Quality Characteristics of Bread Produced from Composite flour or Wheat, plantain and Soybeans", African journal of Biotechnology, 2006, pp.11021106.

[10] Omueti, O. and Ajomale, K.' Chemical and Sensory attributes of Soy-corn milk type', , Journal of food science and technology, 2005, pp. 847-851.

[11] Rotundo, J. L. and Westgate, M. E. 'Meta-Analysis of Environmental Effects on Soybean seed Composition', Field Crops Research, 2009, pp. 147-156.

[12]Salje, K.O.Baishie,M.E. and Mokhter, E.I "'Microbiological Studies on Raw Milk and Yoghurt in ElibeidaCity', unpublished.

[13] Sofu, A.and Ekinci, F.Y. 'Estimation of storage time of yogurt with artificial neural network modeling', Journal of Dairy Science,2007, pp.1825.

[14] Thapa, T. B. "'Small scale milk processing technologies: other milk products.An Electronic Conference, Food and Agriculture Organization of the United Nations"' unpublished.

[15] Trachoo, N. and Mistry, V. V. 'A Application of ultra-filtered Sweet butter milk and Sweet butter milk powder in yoghurt manufacture of non- fat and low fat', Yoghurt. Journal of dairy science, 1998,pp. 774-788. 